\title{
Hemorrhage rate after coblation tonsillectomy: a meta-analysis of published trials
}

\author{
Ralph Mösges • Martin Hellmich • Silke Allekotte • \\ Kerstin Albrecht $\cdot$ Myriam Böhm
}

Received: 9 November 2010/Accepted: 7 February 2011/Published online: 4 March 2011

(c) The Author(s) 2011. This article is published with open access at Springerlink.com

\begin{abstract}
After the surgical procedure of tonsillectomy, hemorrhage ranks among its serious postoperative complications. In this systematic review, we analyze hemorrhage following tonsillectomies performed using the coblation technique. 24 prospective, randomized, and controlled studies were included in the meta-analysis. Data of 796 patients who had undergone coblation tonsillectomy were analyzed. Hemorrhages occurred in 33 patients: 2 classified as primary and 26 as secondary hemorrhages. 5 could not be classified into either group. Overall, the total hemorrhage rate for the coblation procedure was $4.1 \%$ with a $95 \%$ confidence interval from 2.8 to $5.5 \%$. The overall hemorrhage rate of $4.1 \%$ found in this meta-analysis shows that coblation is a safe and effective technique for tonsillectomies with a secondary bleeding rate similar to what is reported for comparable techniques such as bipolar diathermia.
\end{abstract}

Keywords Tonsillectomy · Hemorrhage - Coblation · Radiofrequency-based plasma dissection · Complication

\section{Introduction}

According to recent statistics presented by German university hospitals, approximately every 25 th patient undergoing a tonsillectomy in these hospitals providing maximal medical care must reckon with postoperative hemorrhage (requiring reoperation) (from 1.0 to $9.7 \%$, median 3.8\%)

R. Mösges $(\varangle) \cdot$ M. Hellmich · S. Allekotte · K. Albrecht

M. Böhm

Institute of Medical Statistics,

Informatics and Epidemiology (IMSIE),

University of Cologne, 50924 Cologne, Germany

e-mail: Ralph@Moesges.DE
[1]. The German Federal Office for Quality Assurance [Bundesgeschäftsstelle für Qualitätssicherung (BQS)] reported a hemorrhage rate of $4.7 \%$ for all hospitals in 2003 [2]. Reports of fatal complications go through the press time and again, making both patients and surgeons feel insecure [3]. Also, postoperative pain compromises the patient's recovery since the adequate intake of food and drink can often not be ensured, especially in children $[4,5]$. This situation has led to the development of reportedly "gentler" surgical methods such as that of coblation, also called radiofrequency-based plasma dissection [6]. Contrary to initially publicized euphoria, a Cochrane analysis of morbidity was unable to establish clear positive evidence toward lower peri-operative and postoperative stress on the patient caused by pain and blood loss [7]. In contrast, the focus has recently turned to the frequency of hemorrhages following coblation tonsillectomies. This systematic review will not elaborate on the coblation procedure itself, as comprehensive reports can be found in the literature [8]. Instead, a meta-analysis is to resolve the conflict between the widely differing data on hemorrhage rates in the literature [9]. A reliable assessment of the risk for postoperative hemorrhage would provide valuable support to both patients and surgeons. Even in a systematic review by the National Institute for Health and Clinical Excellence (NICE), contradictory results were found in terms of the incidences of secondary hemorrhages requiring reoperation for the various tonsillectomy procedures [10]. The report expressed a high degree of uncertainty about this assertion due to the low number of secondary hemorrhages at an average of less than $1 \%$ of all operations. For coblation, a lower rate was determined in comparison to the bipolar dissection and hemostasis method across all studies examined. The purpose of the analysis described below is to give a solid estimate of the risk of 
hemorrhage following coblation tonsillectomy based on all prospective, randomized, controlled studies published to date.

\section{Materials and methods}

The objective of this systematic review with a meta-analysis was to collect and evaluate data on the hemorrhage rate after tonsillectomies using the coblation procedure. For this purpose, data were gathered from available publications on randomized, controlled, prospective studies: hemorrhages following tonsillectomy were divided into primary hemorrhages, which occurred within $24 \mathrm{~h}$ following surgery, and secondary hemorrhages, which appeared after $24 \mathrm{~h}$, but especially between the 5th and 10th day after surgery [9]. The hemorrhage rate was recorded as a total result for the analysis and, if specified, classified as primary or secondary hemorrhage. Studies were taken into consideration only if they reported the hemorrhage rate after tonsillectomy using the coblation method. In order to answer the question posed by the metaanalysis in a systematic manner, an overview of the literature available on this topic was compiled. The criteria and set of topics were defined for conducting the systematic analysis of the question at hand. The search terms were determined with these aspects in mind. The terms were combined with one another, and the identified literature was gathered. The keywords were: electrocoagulation/ *methods, tonsillectomy, hemorrhage, coblation, cold ablation, plasma dissection, Arthrocare, tonsillotomy coblation technology, tonsillectomy/*methods, electrosurgery/ *methods, electrosurgery, tonsillectomy/instrumentation*, postoperative complications/epidemiology*, tonsillectomy/ *instruments (Table 1). Data found concerning the research term "tonsillotomy" was not evaluated as relevant by the reviewers and excluded in this meta-analysis since tonsillotomy has a different indication than tonsillectomy and, thus the hemorrhage rates are not comparable.

The systematic review of the literature was carried out using the following electronic databases: Medline; Embase; HTA; NHS EED database; NLCM (National Library of Medicine); Scirus; ISI web of Knowledge and Science, and the user interface Pubmed. We also searched for assessments on the following website: NHS Institute for Health and Clinical Excellence (http://guidance.nice.org.uk/). The literature gathered in the search was then evaluated and data were extracted. Three independent reviewers evaluated the abstracts (R.M., S.A., K.A.). Figure 1 shows the inclusion and exclusion of the references during the review process.

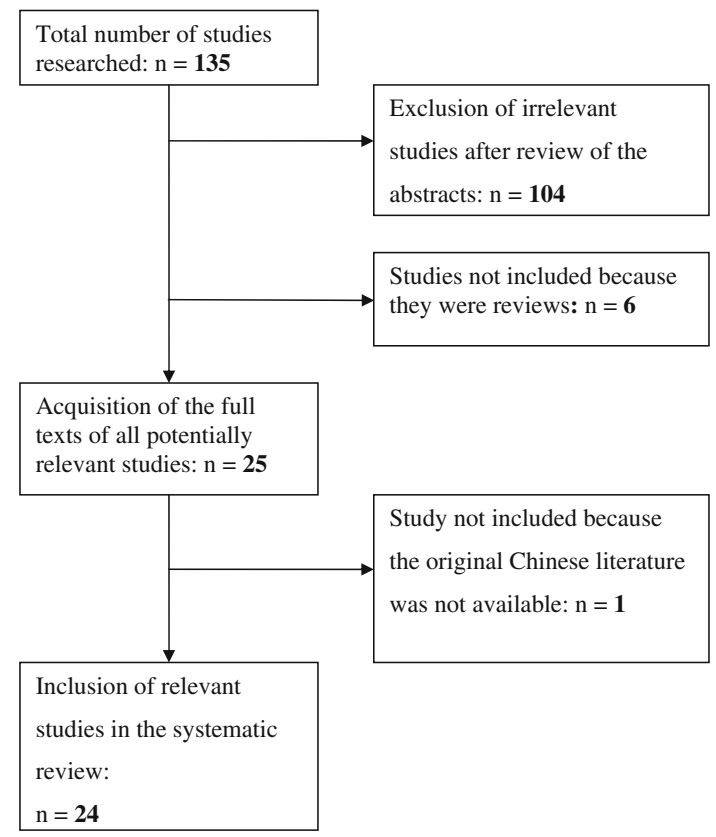

Fig. 1 Study inclusions and exclusions during the review process
Table 1 Literature quest

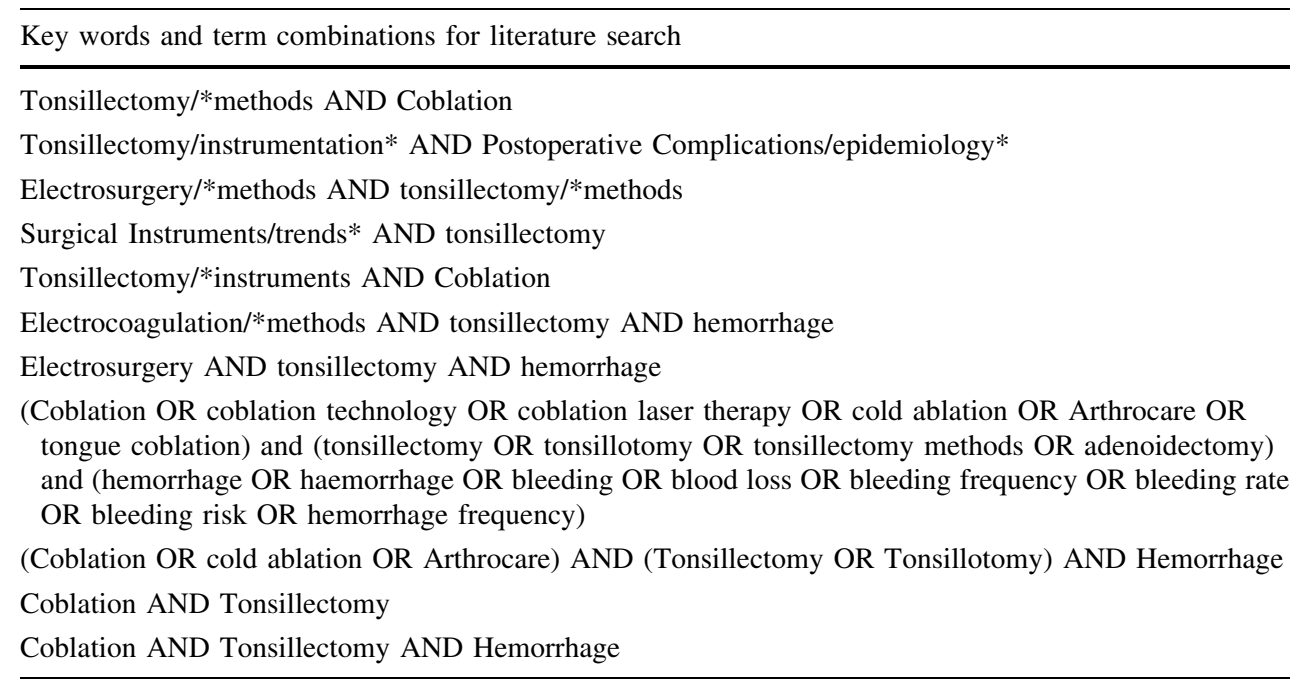


Table 2 Overview studies included in meta-analysis

\begin{tabular}{|c|c|c|c|c|c|c|c|}
\hline References & In- or outpatient & \# patients & $\begin{array}{l}\text { \# TH } \\
\text { CTE }\end{array}$ & $\begin{array}{l}\text { \# PH } \\
\text { CTE }\end{array}$ & $\begin{array}{l}\text { \# SH } \\
\text { CTE }\end{array}$ & $\begin{array}{l}\text { \# "return } \\
\text { to theatre" }\end{array}$ & $\begin{array}{l}\text { Study } \\
\text { location }\end{array}$ \\
\hline Temple and Timms [11] & Outpatient & 18 & 0 & 0 & 0 & $\begin{array}{l}\text { CTE: } 0 \\
\text { Control: } 0\end{array}$ & UK \\
\hline Shah et al. [12] & Outpatient & 17 & 1 & 0 & 1 & $\begin{array}{l}\text { CTE: } 1 \\
\text { Control: } 0\end{array}$ & USA \\
\hline Timms and Temple [13] & Outpatient & 10 & 0 & 0 & 0 & $\begin{array}{l}\text { CTE: } 0 \\
\text { Control: } 0\end{array}$ & UK \\
\hline Arya et al. [14] & Unknown & 14 & 0 & 0 & 1 & Unknown & UK \\
\hline Hall et al. [15] & In- and outpatient & 28 & 2 & - & - & $\begin{array}{l}\text { CTE: } 0 \\
\text { Control: } 0\end{array}$ & USA \\
\hline Stoker et al. [16] & Outpatient & 44 & 4 & 1 & 3 & $\begin{array}{l}\text { CTE: } 0 \\
\text { Control: } 0\end{array}$ & USA \\
\hline Chan et al. [17] & Outpatient & 27 & 1 & 0 & 1 & $\begin{array}{l}\text { CTE: } 0 \\
\text { Control: } 0\end{array}$ & USA \\
\hline Chang [18] & In- and outpatient & 52 & 0 & 0 & 0 & $\begin{array}{l}\text { CTE: } 0 \\
\text { Control: } 0\end{array}$ & USA \\
\hline Philpott et al. [19] & Inpatient & 43 & 11 & 0 & 11 & $\begin{array}{l}\text { CTE: } 0 \\
\text { Control: } 0\end{array}$ & UK \\
\hline Arya et al. [20] & Inpatient & 19 & 1 & 1 & 0 & $\begin{array}{l}\text { CTE: } 0 \\
\text { Control: } 0\end{array}$ & UK \\
\hline Littlefield [21] & Outpatient & 17 & 1 & 0 & 1 & $\begin{array}{l}\text { CTE: } 0 \\
\text { Control: } 0\end{array}$ & USA \\
\hline Parsons et al. [22] & $\begin{array}{l}\text { In- and outpatient } \\
\quad \text { (mostly outpatients) }\end{array}$ & 47 & 1 & - & - & $\begin{array}{l}\text { CTE: } 1 \\
\text { Control 1: } 2 \\
\text { Control 2: } 1\end{array}$ & USA \\
\hline Polites et al. [23] & Inpatient & 19 & 1 & 0 & 1 & $\begin{array}{l}\text { CTE: } 0 \\
\text { Control: } 1\end{array}$ & Australia \\
\hline Noordzij and Affleck [24] & Unknown & 48 & 1 & 0 & 1 & $\begin{array}{l}\text { CTE: } 0 \\
\text { Control: } 2\end{array}$ & USA \\
\hline Tan et al. [25] & Inpatient & 29 & 2 & 0 & 2 & $\begin{array}{l}\text { CTE: } 2 \\
\text { Control: } 0\end{array}$ & Singapore \\
\hline Shapiro and Bhattacharyya [26] & Outpatient & 23 & 1 & 0 & 1 & $\begin{array}{l}\text { CTE: } 1 \\
\text { Control: } 0\end{array}$ & USA \\
\hline Mitic et al. [27] & Outpatient & 20 & 0 & 0 & 0 & $\begin{array}{l}\text { CTE: } 0 \\
\text { Control: } 0\end{array}$ & Norway \\
\hline Chang [28] & Unknown & 69 & 1 & 0 & 1 & CTE: 1 & USA \\
\hline Magdy et al. [29] & Outpatient & 60 & 0 & 0 & 0 & $\begin{array}{l}\text { CTE: } 0 \\
\text { Controls: } 0\end{array}$ & Egypt \\
\hline Hasan et al. [30] & $\begin{array}{l}\text { In- and outpatient } \\
\text { (mostly outpatients) }\end{array}$ & 20 & 1 & 0 & 1 & $\begin{array}{l}\text { CTE: } 1 \\
\text { Control: } 2\end{array}$ & Finland \\
\hline Di Rienzo Businco and Tirelli [31] & Unknown & 21 & 0 & 0 & 0 & $\begin{array}{l}\text { CTE: } 0 \\
\text { Control: } 0\end{array}$ & Italy \\
\hline Roje et al. [32] & Inpatient & 36 & 0 & 0 & 0 & $\begin{array}{l}\text { CTE: } 0 \\
\text { Control: } 0\end{array}$ & Croatia \\
\hline Parker et al. [33] & Inpatient & 37 & 2 & - & - & $\begin{array}{l}\text { CTE: } 0 \\
\text { Control: } 0\end{array}$ & UK \\
\hline D'Eredita and Bozzola [34] & Unknown & 78 & 1 & 0 & 1 & $\begin{array}{l}\text { CTE: } 0 \\
\text { Control: } 0\end{array}$ & Italy \\
\hline
\end{tabular}


After two independent reviewers had extracted the data from the included studies, the data were analyzed by means of a statistical procedure.

Statistical methods

For the meta-analysis, the proportions of the individual studies were Freeman-Tukey transformed [35] to enable the application of the common methods for fixed and random effects [6]. The pooled proportion was then calculated by inverse transformation of the weighted averages of the transformed proportions. In the forest plot, the proportions are depicted with $95 \%$ confidence intervals according to Clopper and Pearson [36], with the surface of the squares (point estimates) being proportional to the case number of the particular study. Funnel plots were tested for asymmetry [37]. The analysis was conducted in R 2.9.2 [38] (Library meta [39]).

\section{Results}

Analysis of the literature

Overall, 24 randomized, prospective and controlled studies were taken into consideration (Table 2). The studies varied in terms of study population. For the analysis, subgroups were therefore formed according to age (adults and children) (Table 3).

\section{Heterogeneity}

In the subgroup of adult patients the studies showed a moderate degree of heterogeneity in terms of the total hemorrhage rate $\left[I^{2}=61.6 \%(26 ; 80.1)\right]$ (Fig. 2) and the secondary hemorrhage rate $\left[I^{2}=67.6 \%(35.1 ; 84)\right]$ (Fig. 4).

Publication bias (effects of smaller studies)

Funnel plots and tests for asymmetry yielded no conclusive indications of relevant biases. If they indeed exist, then an overestimation of the pooled proportions, i.e. hemorrhage rates, appears to be plausible (few, upward-tending study results).

Patients

The pooling of all included studies resulted in a total of 796 patients. These could be subdivided into two age groups, one consisting of 461 children and the other of 335 adults. With regard to the child study population, the studies had various age limits. In our analysis, study participants $<18$ years of age were classified as children. Only patients whose age was certain were assigned to one of the age groups. Only those studies with a clear assignment of patients were included in the subgroup analysis.

Postoperative hemorrhage

Of all tonsillectomies performed using coblation, an overall hemorrhage incidence resulted for 33 patients. Of these, 2 could be classified as primary and 26 as secondary hemorrhages. 5 patients could not be classified into either group. Overall, the hemorrhage rate for the coblation procedure based on the 24 available studies was $4.1 \%$ (95\% CI $0.028-0.055)$ when assuming the so-called fixed effect model and $4.4 \%$ (95\% CI 0.026-0.066) for the random effects model across all studies analyzed (Fig. 2). If only the results of the subgroup children are taken into account, the hemorrhage rate is $2.9 \%$ (fixed effect model, 95\% CI $0.016-0.047$ ) and $3.0 \%$ (random effects model, 95\% CI 0.016-0.048). Taking the results of the subgroup adults into consideration, the result is $5.8 \%$ (95\% CI 0.036-0.086) for the fixed effect model and $6.4 \%$ (95\% CI $0.027-0.114$ ) for the random effects model.

Primary hemorrhage

Of all 21 studies that classified postoperative hemorrhage, the primary hemorrhage rate for the fixed effect model was $0.9 \% \quad(95 \%$ CI $\quad 0.003-0.017)$ and $0.9 \% \quad(95 \%$ CI 0.003-0.017) for the random effects model (Fig. 3). The data analysis of all adult patient data results in a
Table 3 Overview postoperative hemorrhage rates over all studies

\begin{tabular}{lllll}
\hline Age group & $\begin{array}{l}\text { Number of } \\
\text { studies }\end{array}$ & $\begin{array}{l}\text { Primary } \\
\text { hemorrhage }\end{array}$ & $\begin{array}{l}\text { Secondary } \\
\text { hemorrhage }\end{array}$ & $\begin{array}{l}\text { Total } \\
\text { hemorrhage }\end{array}$ \\
\hline Adults + children & 24 & $0.9 \%(n=21)$ & $3.6 \%(n=21)$ & $4.1 \%(n=24)$ \\
& \multirow{2}{*}{11} & $95 \%$ CI $0.3-1.7$ & $95 \%$ CI $2.3-5.1$ & $95 \%$ CI $2.8-5.5$ \\
Adults & \multirow{2}{*}{13} & $9.8 \%(n=9)$ & $6.2 \%(n=9)$ & $5.8 \%(n=11)$ \\
& & $95 \%$ CI $0.08-2.2$ & $95 \%$ CI 3.6-9.4 & $95 \%$ CI 3.6-8.6 \\
Children & $1.0 \%(n=12)$ & $2.3 \%(n=12)$ & $2.9 \%(n=13)$ \\
& $95 \%$ CI $0.3-2.1$ & $95 \%$ CI $1.1-4.0$ & $95 \%$ CI $1.6-4.7$ \\
\hline
\end{tabular}


Fig. 2 Total hemorrhage rate, test for heterogeneity:

$\chi^{2}=258.82, d f=37$,

$p<0.0001, I^{2}=85.7 \%$. Test

for overall effect: $z=11.8925$, $p<0.0001$

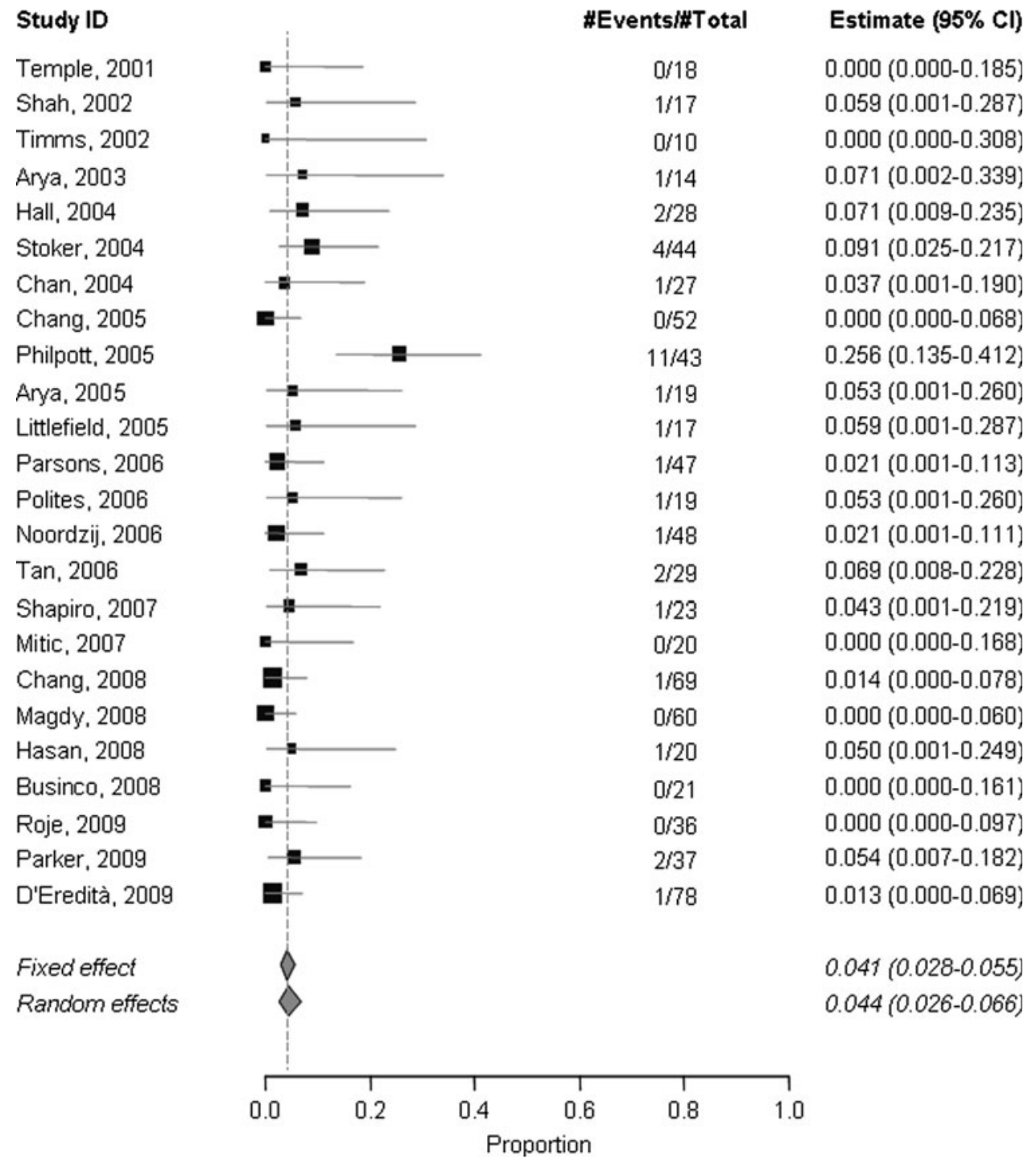

hemorrhage rate of $0.8 \%$ for both models (identical 95\% CI for both models, 0.0008-0.022). For the children, the use of both models likewise yields hemorrhage rates of $1.0 \%$ (with identical 95\% CI 0.003-0.021).

Secondary hemorrhage

The analysis of all available data on secondary hemorrhage results in a rate of $3.6 \%$ for the fixed effect model $(95 \% \mathrm{CI}$ $0.023-0.051)$ and $3.9 \%$ for the random effects model $(95 \%$ CI 0.021-0.063) (Fig. 4). When differentiating among the age groups, the resulting secondary hemorrhage rate is $6.2 \%$ (fixed effect model, 95\% CI 0.036-0.094) and 6.8\% (random effects model, 95\% CI 0.023-0.134) for the adult group. Upon inspection and evaluation of the secondary hemorrhage rates of children, both models likewise yield hemorrhage rates of $2.3 \%$ with identical $95 \%$ CI for both models (95\% CI 0.011-0.040).

\section{Discussion}

There is still no generally accepted definition of the term hemorrhage with regard to post-tonsillectomy hemorrhage available. Different authors may use varying definitions of hemorrhage depending on their technique used for assessing hemorrhage, e.g. macroscopic evaluation or by microscope. Some publications focused solely on the need to return to theater, meaning hemorrhage requiring reoperation, whereas other studies recorded all postoperative hemorrhages. The discrepancies in definitions of secondary bleeding led to a big variation in figures stated in various publications. Thus, bleeding rate percentages have to be interpreted carefully. This should also to be taken into account when interpreting the results of this study.

Moreover, in Europe, no consensus concerning the term "inpatient" and "outpatient" with regard to the duration of stay in hospital exists [40]. In Germany and Austria for 
Fig. 3 Primary hemorrhage rate, test for heterogeneity:

$\chi^{2}=5.59, d f=20$,

$p=0.9993, I^{2}=0 \%$. Test for

overall effect: $z=4.9947$,

$p<0.0001$

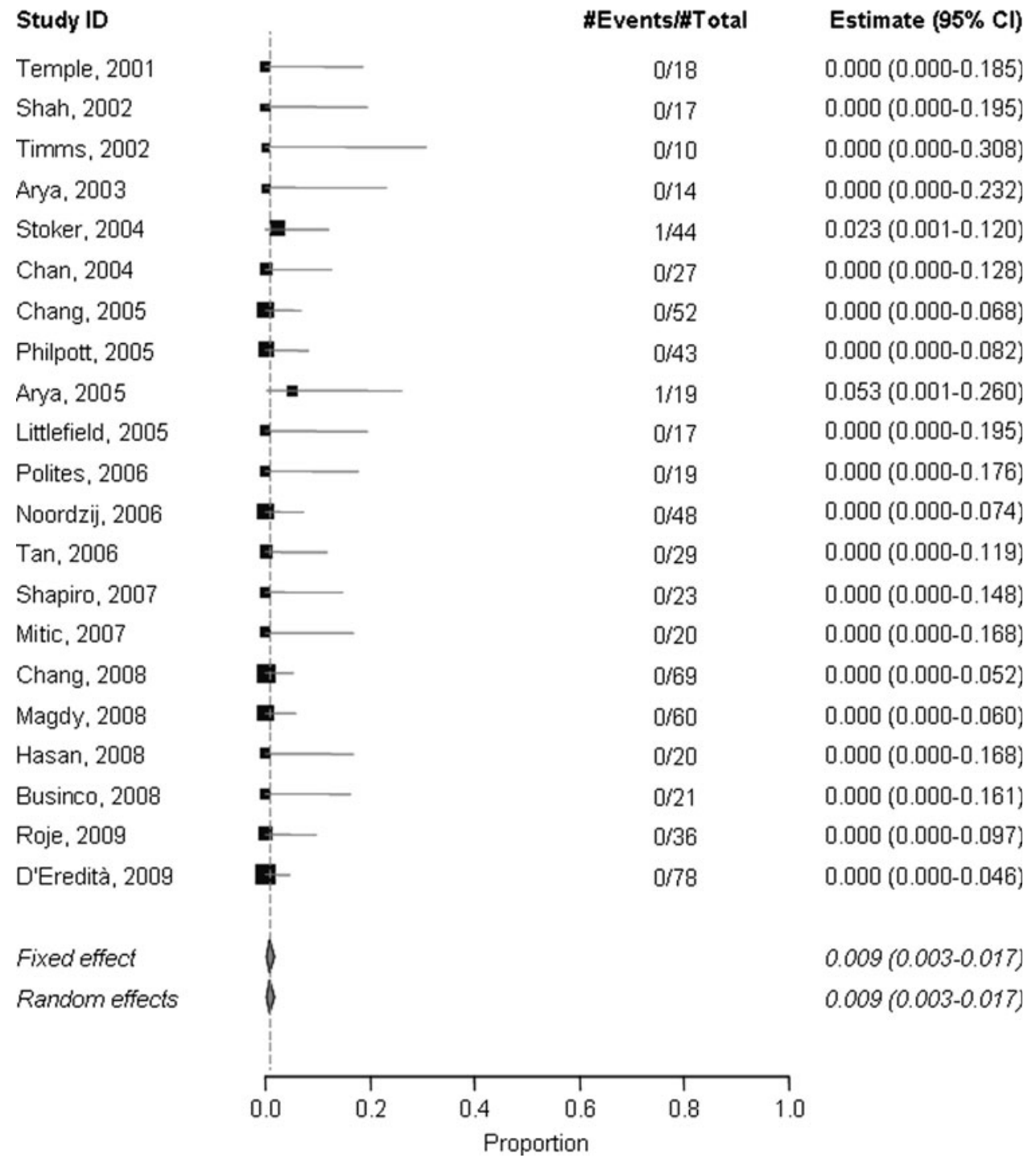

example, some inpatients stay 5 days postoperatively in hospital, whereas in the UK and Sweden an inpatient mostly stays overnight after surgery. These differing treatment patterns in various countries also have to be taken into account when analyzing bleeding rates (Table 2).

In May 2005 the Royal College of Surgeons of England published the data from the National Prospective Audit of Tonsillectomy (NPTA), which analyzed over 40,514 operation records in England and Northern Ireland [41]. In this report, four different applications of "electrosurgery" were discussed; in particular, the various applications of diathermy such as dissection or hemostasis (bipolar with forceps or scissors/monopolar) and coblation. These were compared with cold steel dissection when used in combination with various hemostasic procedures (hemostasis with ties and/or packs, with bipolar or monopolar diathermy). The two most common surgical techniques observed were cold steel dissection combined with bipolar diathermy for hemostasis (35\%), followed by bipolar diathermy forceps (30\%). Five percent of all patients underwent an operation using the coblation procedure. In the NPTA final report, focus was placed on postoperative hemorrhage, classifying it into primary and secondary hemorrhage rates. Comparing the two radiofrequencybased techniques for tonsillectomy, overall postoperative hemorrhage rates for bipolar diathermy and coblation were identical (4.6\%). The differences between both techniques were mostly reflected by variations in the secondary bleeding rates. While primary bleeding events are often caused by insufficient intraoperative hemostasis, secondary hemorrhage is frequently related to the rejection of the wound surface and fibrinogen degeneration during wound healing determined by the surgical technique used for tonsillectomy [42]. According to the NPTA report, the secondary bleeding rate with coblation was found to be $3.6 \%$, falling between the hemorrhage rates reported for 
Fig. 4 Secondary hemorrhage rate, test for heterogeneity:

$\chi^{2}=39.61, d f=20$,

$p=0.0056, I^{2}=49.5 \%$. Test

for overall effect: $z=7.1576$, $p<0.0001$

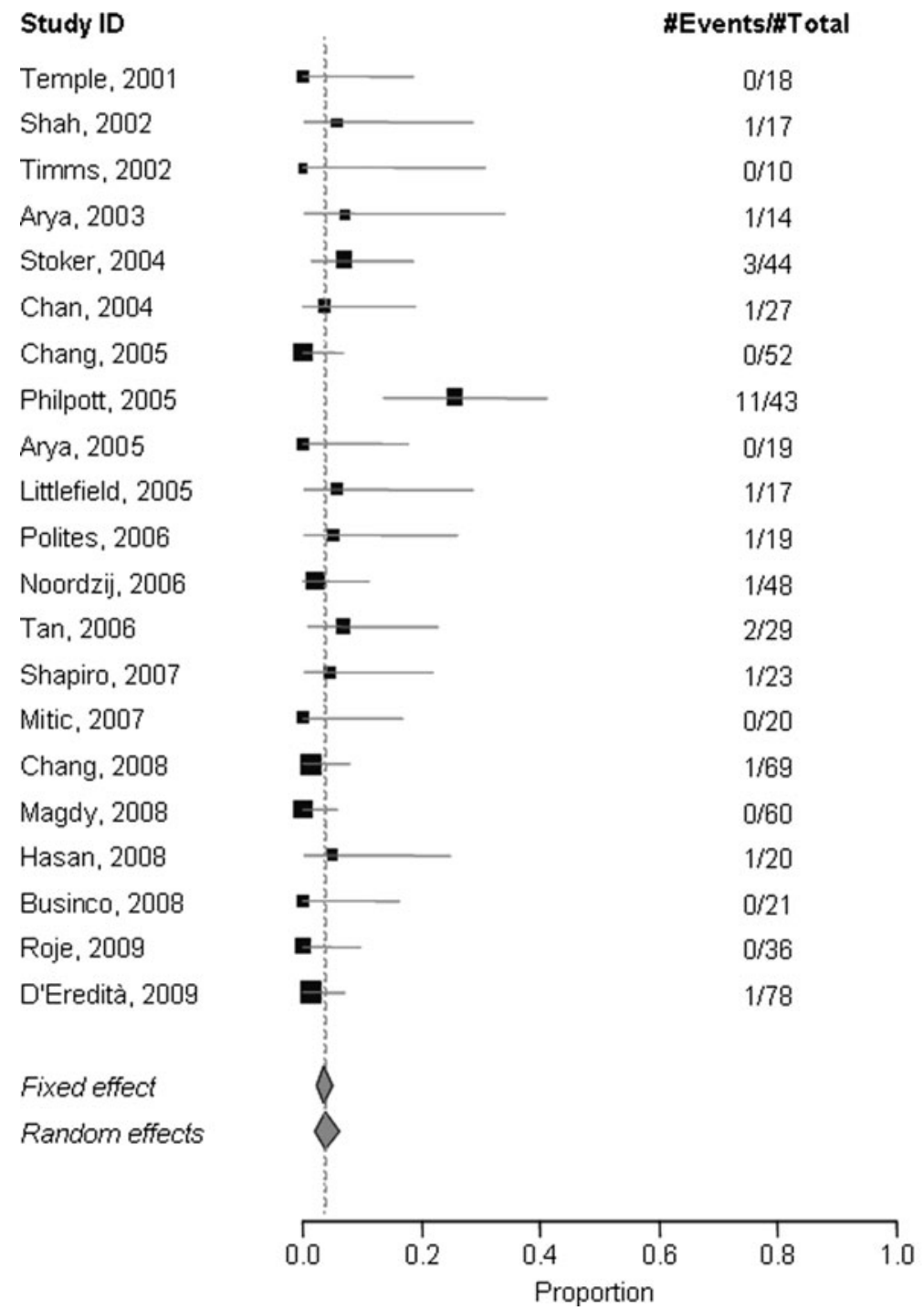

Estimate $(95 \% \mathrm{Cl})$

$0.000(0.000-0.185)$

$0.059(0.001-0.287)$

$0.000(0.000-0.308)$

$0.071(0.002-0.339)$

$0.068(0.014-0.187)$

$0.037(0.001-0.190)$

$0.000(0.000-0.068)$

$0.256(0.135-0.412)$

$0.000(0.000-0.176)$

$0.059(0.001-0.287)$

$0.053(0.001-0.260)$

$0.021(0.001-0.111)$

$0.069(0.008-0.228)$

$0.043(0.001-0.219)$

$0.000(0.000-0.168)$

$0.014(0.000-0.078)$

$0.000(0.000-0.060)$

$0.050(0.001-0.249)$

$0.000(0.000-0.161)$

$0.000(0.000-0.097)$

$0.013(0.000-0.069)$

$0.036(0.023-0.051)$

$0.039(0.021-0.063)$ cold steel with bipolar diathermy (2.3\%) and bipolar diathermy forceps $(4.4 \%)$. Regarding reoperation for postoperative hemorrhage, both electrosurgical tonsillectomy techniques required a slightly higher rate of reoperation than following the cold steel method with bipolar diathermy ( 0.7 as opposed to $0.4 \%)$.

Divergent trends pertaining to the use of coblation and bipolar diathermy could be found for different parts of the United Kingdom [43]. The Wales Single-use Instrument Surveillance Programme (SISP), which involved 3,690 patients who underwent tonsillectomy during the period from February 2003 to March 2004, indicates that the electrosurgery techniques were used less frequently than in England and Northern Ireland. In the SISP registry report secondary hemorrhage requiring return to theater after cold steel dissection with bipolar diathermy was found to be $0 \%$ (95\% CI 0-2.7\%). The rate of return to theater concerning bipolar diathermy was $2.2 \%$, with coblation $(0.5 \%)$ lying between cold steel with bipolar diathermy and bipolar diathermy hemorrhage rates. When taking into account the partially overlapping confidence intervals, it can be assumed that coblation, compared to the classical surgery technique and bipolar diathermy, is a safe method for tonsillectomy.

Another point that deserves to be mentioned is that some authors [44, 45] report about standardized premedication in children, as well as intraoperative pain therapy and postoperative treatment of pain with nonsteroidal anti-inflammatory drugs (NSAIDs). In a meta-analysis, Moiniche et al. [46] observe that under this form of pain therapy, reoperations due to hemorrhage are necessary at an average of more than twice as often $(\mathrm{OR}=2.33)$.

Possible sources of the heterogeneity of the total hemorrhage rates identified in the adult subgroup could lie in the unequal degrees of surgeons' operative experience, but they could also be due to the varying patient compliance, smoking habits, co-morbidity, condition of the tonsils, or coagulation disorders. 
Our data shows a higher hemorrhage rate in the adult subgroup (5.8\%) compared to the child subgroup $(2.9 \%)$. This finding is in line with previous studies [47-53] which also demonstrate an age-dependence for post-tonsillectomy bleeding. This age-dependence is attributed to the fact that older patients have suffered from recurring infections of the tonsils [53] and that patient noncompliance with regard to postoperative management including dietary intake and physical rest increases in the age group between 11 and 40 years [48, 51].

Parental supervision contributes directly to high compliance rates, as children have less freedom of dietary intake after tonsillectomy than adults have. Moreover, it can be assumed that children suffer from less co-morbidity than adults. These assumptions are also consistent with the findings of Myssiorek et al. [50] and Carmody et al. [49] who show that age is a significant risk factor for posttonsillectomy hemorrhages, since older patients more often have a history of chronic tonsillitis and are allowed more freedom of dietary intake postoperatively. Consequently, this may lead to an increased risk of secondary hemorrhage due to dietary trauma, as suggested by the increased incidence of bleeding between days 5 and 12, a period when eating increases as the odynophagia wanes away.

Very low hemorrhage rates were observed in individual studies. Nevertheless, in one study an even more significantly raised hemorrhage rate was observed. The latter [19] was far beyond the $95 \%$ confidence interval of $2.8-5.5 \%$ published in the literature, and might possibly have to be interpreted in terms of an autodidactic learning process as previously described in [54]. In light of this analysis, it appears reasonable that as with any other surgical technique, sufficient and proper training is essential. In the hands of trained surgeons, the coblation method does not appear to generate a high hemorrhage rate.

\section{Conclusion}

Based on our findings from the meta-analysis, we conclude that coblation is a safe and effective method for tonsillectomy compared to other radiofrequency-based techniques. Nevertheless, every bleeding, regardless of the technique chosen for the tonsillectomy, is a life-threatening event and needs to be treated with utmost care. This analysis clearly showed that there is need for a consistent definition of bleeding after tonsillectomies, as proposed by the Austrian Survey on tonsillectomy. ${ }^{1}$

\footnotetext{
${ }^{1}$ S. Sarny and W. Habermann (Graz), Presentation of results and data analysis of the Austrian Tonsillectomy Study 2009/2010, 54th Annual Meeting of the Austrian Society of Oto-Rhino-Laryngology, Head and Neck Surgery, Salzburg, 2010.
}

Conflict of interest The authors declare that no conflict of interest exists. The corresponding author R.M. has served as a scientific advisor for Arthrocare Deutschland, $\mathrm{GmbH}$, and presented an honored lecture at a presentation of the manufacturer. The present publication has been prepared under no influence by the manufacturer in the context of a university research project. It was financed with university third-party funds also using an unrestricted research grant provided by the manufacturer Arthrocare Deutschland.

Open Access This article is distributed under the terms of the Creative Commons Attribution Noncommercial License which permits any noncommercial use, distribution, and reproduction in any medium, provided the original author(s) and source are credited.

\section{References}

1. Tonsillektomie-Nachblutung (2009) Spitzenmedizin der Deutschen Hochschulmedizin-Qualität leben. Verband der Universitätsklinika Deutschlands e.V. VUD, Berlin

2. Diagnosen und Prozeduren der vollständigen Patienten und Patientinnen in Krankenhäusern (2008). Statistisches Bundesamt

3. Kerst M (2003) Nach Mandelentzündung verbluteten zwei Patienten. Express, 20.10.2003

4. Husband AD, Davis A (1996) Pain after tonsillectomy. Clin Otolaryngol Allied Sci 21(2):99-101

5. Randall DA, Hoffer ME (1998) Complications of tonsillectomy and adenoidectomy. Otolaryngol Head Neck Surg 118(1):61-68. doi:10.1016/S0194-5998(98)70376-6

6. DerSimonian R, Laird N (1986) Meta-analysis in clinical trials. Control Clin Trials 7(3):177-188. doi:10.1016/0197-2456(86) 90046-2

7. Burton MJ, Doree C (2007) Coblation versus other surgical techniques for tonsillectomy. Cochrane Database Syst Rev (3):CD004619. doi:10.1002/14651858.CD004619.pub2

8. Bortnick DP (2001) Coblation: an emerging technology and new technique for soft-tissue surgery. Plast Reconstr Surg 107(2): $614-615$

9. Scheckenbach K, Bier H, Hoffmann TK, Windfuhr JP, Bas M, Laws HJ, Plettenberg C, Wagenmann M (2008) Risk of hemorrhage after adenoidectomy and tonsillectomy. Value of the preoperative determination of partial thromboplastin time, prothrombin time and platelet count. HNO 56(3):312-320. doi: 10.1007/s00106-007-1585-x

10. Electrosurgery (diathermy and coblation) for tonsillectomy (2005) Interventional procedure guidance 150. National Institute for Health and Clinical Excellence, London

11. Temple RH, Timms MS (2001) Paediatric coblation tonsillectomy. Int J Pediatr Otorhinolaryngol 61 (3):195-198. doi: 10.1016/s0165-5876(01)00553-5

12. Shah UK, Galinkin J, Chiavacci R, Briggs M (2002) Tonsillectomy by means of plasmamediated ablation: prospective, randomized, blinded comparison with monopolar electrosurgery. Arch Otolaryngol Head Neck Surg 128(6):672-676

13. Timms MS, Temple RH (2002) Coblation tonsillectomy: a double blind randomized controlledstudy. J Laryngol Otol 116(6): 450-452. doi:10.1258/0022215021911031

14. Arya A, Donne AJ, Nigam A (2003) Double-blind randomized controlled study of coblation tonsillotomy versus coblation tonsillectomy on postoperative pain. Clin Otolaryngol Allied Sci 28(6):503-506. doi:10.1046/j.1365-2273.2003-00750-x

15. Hall DJ, Littlefield PD, Birkmire-Peters DP, Holtel MR (2004) Radiofrequency ablation versus electrocautery in tonsillectomy. Otolaryngol Head Neck Surg 130(3):300-305. doi:10.1016/ j.otohns.2003.09.024 
16. Stoker KE, Don DM, Kang DR, Haupert MS, Magit A, Madgy DN (2004) Pediatric total tonsillectomy using coblation compared to conventional electrosurgery: a prospective, controlled single-blind study. Otolaryngol Head Neck Surg 130 (6):666675. doi:10.1016/j.otohns.2004.02.012

17. Chan KH, Friedman NR, Allen GC, Yaremchuk K, Wirtschafter A, Bikhazi N, Bernstein JM, Kelley PE, Lee KC (2004) Randomized, controlled, multisite study of intracapsular tonsillectomy using low-temperature plasma excision. Arch Otolaryngol Head Neck Surg 130(11):1303-1307. doi:10.1001/archotol.130. 11.1303

18. Chang KW (2005) Randomized controlled trial of Coblation versus electrocautery tonsillectomy. Otolaryngol Head Neck Surg 132(2):273-280. doi:10.1016/j.otohns.2004.11.002

19. Philpott CM, Wild DC, Mehta D, Daniel M, Banerjee AR (2005) A double-blinded randomized controlled trial of coblation versus conventional dissection tonsillectomy on post-operative symptoms. Clin Otolaryngol 30(2):143-148. doi:10.1111/j.1365-2273. 2004.00953.x

20. Arya AK, Donne A, Nigam A (2005) Double-blind randomized controlled study of coblation tonsillotomy versus coblation tonsillectomy on postoperative pain in children. Clin Otolaryngol 30(3):226-229

21. Littlefield PD, Hall DJ, Holtel MR (2005) Radiofrequency excision versus monopolar electrosurgical excision for tonsillectomy. Otolaryngol Head Neck Surg 133(1):51-54. doi:10.1016/j.otohns. 2005.02.013

22. Parsons SP, Cordes SR, Comer B (2006) Comparison of posttonsillectomy pain using the ultrasonic scalpel, coblator, and electrocautery. Otolaryngol Head Neck Surg 134(1):106-113. doi:10.1016/j.otohns.2005.09.027

23. Polites N, Joniau S, Wabnitz D, Fassina R, Smythe C, Varley P, Carney AS (2006) Postoperative pain following coblation tonsillectomy: randomized clinical trial. ANZ J Surg 76(4):226-229. doi:10.1111/j.1445-2197.2006.03700.x

24. Noordzij JP, Affleck BD (2006) Coblation versus unipolar electrocautery tonsillectomy: a prospective, randomized, single-blind study in adult patients. Laryngoscope 116(8):1303-1309. doi: 10.1097/01.mlg.0000225944.00189.e9

25. Tan AK, Hsu PP, Eng SP, Ng YH, Lu PK, Tan SM, Say JH, Chan YH (2006) Coblation vs electrocautery tonsillectomy: postoperative recovery in adults. Otolaryngol Head Neck Surg 135(5): 699-703 doi:10.1016/j.otohns.2006.03.008

26. Shapiro NL, Bhattacharyya N (2007) Cold dissection versus coblation-assisted adenotonsillectomy in children. Laryngoscope 117(3):406-410. doi:10.1097/MLG.0b013e31802ffe47

27. Mitic S, Tvinnereim M, Lie E, Saltyte BJ (2007) A pilot randomized controlled trial of coblation tonsillectomy versus dissection tonsillectomy with bipolar diathermy haemostasis. Clin Otolaryngol 32(4):261-267. doi:10.1111/j.1365-2273. 2007.01468.x

28. Chang KW (2008) Intracapsular versus subcapsular coblation tonsillectomy. Otolaryngol Head Neck Surg 138(2):153-157. doi: 10.1016/j.otohns.2007.11.006

29. Magdy EA, Elwany S, el-Daly AS, Abdel-Hadi M, Morshedy MA (2008) Coblation tonsillectomy: a prospective, double-blind, randomised, clinical and histopathological comparison with dissection-ligation, monopolar electrocautery and laser tonsillectomies. J Laryngol Otol 122(3):282-290. doi:10.1017/S0022 21510700093X

30. Hasan H, Raitiola H, Chrapek W, Pukander J (2008) Randomized study comparing postoperative pain between coblation and bipolar scissor tonsillectomy. Eur Arch Otorhinolaryngol 265(7): 817-820. doi:10.1007/s00405-007-0537-0

31. Di Rienzo Businco L, Coen Tirelli G (2008) Paediatric tonsillectomy: radiofrequency-based plasma dissection compared to cold dissection with sutures. Acta Otorhinolaryngol Ital 28(2):67-72

32. Roje Z, Racic G, Dogas Z, Pisac VP, Timms M (2009) Postoperative morbidity andhistopathologic characteristics of tonsillar tissue following coblation tonsillectomy in children: aprospective randomized single-blind study. Coll Antropol 33(1):293-298

33. Parker D, Howe L, Unsworth V, Hilliam R (2009) A randomised controlled trial to compare postoperative pain in children undergoing tonsillectomy using cold steel dissection with bipolar haemostasis versus coblation technique. Clin Otolaryngol 34(3):225-231. doi::10.1111/j.1749-4486.2009.01932.x

34. D'Eredita R, Bozzola L (2009) Molecular resonance vs. coblation tonsillectomy in children. Laryngoscope 119(10):1897-1901. doi:10.1002/lary.20210

35. Mosteller F, Youtz C (1961) Tables of the Freeman-Tukey transformations for the binomial and Poisson distributions. Biometrika 48(3-4):433-440

36. Clopper C, Pearson E (1934) The use of confidence or fiducial limits illustrated in the case of the binomial. Biometrika 26(4):404-413

37. Thompson SG, Sharp SJ (1999) Explaining heterogeneity in meta-analysis: a comparison of methods. Stat Med 18(20): 2693-2708. doi:10.1002/(SICI)1097-0258(19991030)18:20 $<2693:: A I D-S I M 235>3.0 . C O ; 2-\mathrm{V}$

38. Team RDC (2009) R: a language and environment for statistical computing. R Foundation for Statistical Computing, Vienna, Austria

39. Schwarzer G (2009) meta: Meta-Analysis with R. R package version 1.1-4. http://CRAN.R-project.org/package $=$ meta

40. Schmelzer B, Peeters A (1999) Tonsillectomy and adenoidectomy: postoperative management in European countries. Laryngorhinootologie 78(11):594-595. doi:10.1055/s-1999-12970

41. National prospective tonsillectomy audit—final report (2005). Royal College of Surgeons, London

42. Schmidt H, Schmiz A, Stasche N, Hormann K (1996) Surgically managed postoperative hemorrhage after tonsillectomy. Laryngorhinootologie 75(8):447-454. doi:10.1055/s-2007-997613

43. Mowatt G, Cook J, Fraser C, Burr J (2005) Systematic review of the safety and efficacy of electrosurgery for tonsillectomy. Review body report submitted to the Interventional Procedures Programme, National Institute for Health and Clinical Excellence

44. Windfuhr JP, Deck JC, Krabs C, Sadra R, Remmert S (2006) Coblation tonsillectomy. Results of a pilot study. HNO 54(3):190-197. doi:10.1007/s00106-005-1308-0

45. Schmidt A, Bjorkman S, Akeson J (2001) Preoperative rectal diclofenac versus paracetamol for tonsillectomy: effects on pain and blood loss. Acta Anaesth Scand 45(1):48-52

46. Moiniche S, Romsing J, Dahl JB, Tramer MR (2003) Nonsteroidal antiinflammatory drugs and the risk of operative site bleeding after tonsillectomy: a quantitative systematic review. Anesth Analg 96(1):68-77

47. Windfuhr JP, Chen YS, Remmert S (2005) Hemorrhage following tonsillectomy and adenoidectomy in 15, 218 patients. Otolaryngol Head Neck Surg 132(2):281-286. doi:10.1016/j.otohns. 2004.09.007

48. Roberts C, Jayaramachandran S, Raine CH (1992) A prospective study of factors which may predispose to post-operative tonsillar fossa haemorrhage. Clin Otolaryngol Allied Sci 17(1):13-17

49. Carmody D, Vamadevan T, Cooper SM (1982) Post tonsillectomy haemorrhage. J Laryngol Otol 96(7):635-638

50. Myssiorek D, Alvi A (1996) Post-tonsillectomy hemorrhage: an assessment of risk factors. Int $\mathrm{J}$ Pediatr Otorhinolaryngol 37(1):35-43. (pii:016558769601364X)

51. Kristensen S, Tveteras K (1984) Post-tonsillectomy haemorrhage. A retrospective study of 1150 operations. Clin Otolaryngol Allied Sci 9(6):347-350 
52. Rosenfeld RM, Green RP (1990) Tonsillectomy and adenoidectomy: changing trends. Ann Otol Rhinol Laryngol 99(31):187-191 53. Schrock A, Send T, Heukamp L, Gerstner AO, Bootz F, Jakob M (2009) The role of histology and other risk factors for post-tonsillectomy haemorrhage. Eur Arch Otorhinolaryngol 266(12): 1983-1987. doi:10.1007/s00405-009-0958-Z
54. Carney AS, Harris PK, MacFarlane PL, Nasser S, Esterman A (2008) The coblation tonsillectomy learning curve. Otolaryngol Head Neck Surg 138(2):149-152. doi:10.1016/j.otohns.2007. 10.031 